spaces,-none were found on the portions of pleura corresponding to the ribs.

From these experiments certain important practical deductions can be drawn.

I. That although in the early stages of pleurisy the respiratory movements tend to spread and intensify the pleuritic process, in a later stage they tend to promote reabsorption of the fluid effusion.

II. The fact that the absorption of minute solid particles from the pleural cavity is brought about by the stomata and lymphatics of the costal pleuræ, is of clinical importance in that when in a case of pleuritic effusion, approximation of the ribs has occurred, these stomata and lymphatics will be rendered correspondingly incapable of performing their function. Further, the mobility of the side being correspondingly impaired, the benefit of the respiratory movements will be to an equal extent awanting.

III. The fact that by breathing an attenuated atmosphere the process of reabsorption is favoured, is of importance in connexion with the ærotherapeutics of pleuritic effusion.

\title{
IV.-SCANDINAVIAN STUDIES.
}

\section{By JoHn BoxD, M.D., Slamannan.}

There is abundant evidence that the countrymen of Linnæus and Berzelius are still advancing strenuously in the paths of scientific progress. From the number and importance of the medical publications we have received from Stockholm, I have for some time past felt it would be becoming to make mention of them in the pages of the Edinburgh Medical Journal, which might be of interest to the readers thereof.

The first booklet I shall discuss is by Dr Otto G. Wetterstrand, entitled, On Hypnotism applied to Practical Medicine (Om Hypnotismens Användande $i$ den Praktiska Medicinen), pp. 90, stated in his förord or preface to be written entirely for medical men, calling their attention to a method of treatment which he has found successful when other therapeutic agencies have proved powerless. This designation combines a number of different conditions of the nervous system, variously called forth, including all degrees, from a slight sensation of torpor of the extremities to the deepest slumber, whence the subject cannot be wakened by the loudest sound; where all sensation is abolished, so that serious surgical operations might be performed utterly unfelt by him, and, in Ovid's words, he is "gelidæ mortis imago." The susceptibility to be so influenced is very general. Out of 1011 subjects Liébault found only 27 inoperable; the author only 19 of 718 hypnotised by him since the beginning of 1887 did he find intractable. As to temperament, he noticed that nervous persons are most difficult, and in this point he dis- 
agrees with Charcot and his pupil Bottey, who would connect it with hysteria. The most marked case of somnambulism he ever encountered was in a healthy 17 year old girl (frisk 17-arig flicka), who had never been ill a day in her life. As to character, he found egotists less easily operated on than nobler natures, but the highest and deepest intellects were equally open to suggestions with those barely above idiocy. Age is an important factor. Children from 3 or 4 to 15 are susceptible, up to 30 years-after which there is less aptitude. However, some old people are easily enough affected, in evidence of which he details the case of a female of 69 , who was effectually relieved by it from incontinentia urinæ diurna et nocturna of some years'duration. The method of Bernheim in his important work on suggestion is that used by Wetterstrand, who also quotes respectfully the work of Braid, 1843, but considers a Portuguese priest, Abbé Faria, who wrote in 1815, as having somewhat forestalled him. He proceeds to describe the various degrees of the hypnotic state, which Liébault divides into five.

1 st grade, in which the patient lies still, feels a certain sleepiness and heaviness, understands all going on around him; no catalepsy.

$2 n d$ grade, a deeper state; patient cannot open his eyelids, cannot move his body or limbs; the catalepsy is most charac-
teristic.

$3 r d$ grade is marked by automatic movements, which can be called forth by the operator-rotation of arms, etc., continued till made to desist.

tion grade is distinguished by the patient being in direct relaafterwarts operator, hearing his voice alone, and remembering Thards what he said, but no one else.

The 5th grade is the deepest and most exquisite form, in which sensibility is deadened, and the relations between operator and subject the most complete. The suggestions of the former tell on the latter with lightning rapidity.

Dr Wetterstrand next describes the modus operandi as applied by Liébault by vocal utterances, in firm cries fixing the patient's attention, and ordering the morbid symptoms to disappear-which implies some special power or nerve force on the part of the physician.

The method of Braid is applicable sometimes, particularly if the other plan fails. Then follow a series of cases of this treatment on nervous cephalalgia, of which I shall translate two as specimens of the author's claims:-

1. Hanna B., single, 19. For three years past she has suffered every morning from severe headaches. She is unfit for work till forenoon, but after midday feels better, though never free from pain. She looks pale, but cannot be called anæmic. Has slight gastric symptoms, but infrequent, and cannot be connected with 
her head suffering. On the $1 / 51886$ I hypnotised her the first visit to the third grade, and after the second to somnambulism. In all she received six operations, and on the $19 / 5$ was perfectly well.

2. Elise R., married, 33; headache for eight or eight and a half years every day; head heavy, and feels as if icy cold; sometimes giddiness comes on so severe that she cannot walk on the streets from fear of falling; feels heavy and weary, unfit for locomotion; appetite feeble; no organic symptom, but pale and thin. The first séance, $3 / 5$, to somnambulism; $9 / 5$, perfectly well, free from all sickness, and appetite good.

A number of cases of chorea are recounted wherein similar success was obtained, as also one of spasmodic convulsions; but of special interest are the results of hypnotism in stammering, as for example:- " On the 2/4 I hypnotised Maria M., 32, a strong, powerfully-built woman, but from infancy suffering from stammering in the highest degree, so that sometimes she could not utter a single word. To my surprise, when hypnotised, she stammered none-spoke freely and fluently. She is specially somnambulent; in that condition could be made to converse at will, but could not begin a topic, answering my questions. I could make her open her eyes, walk through the room, sit down and write, or read a book, without a trace of her infirmity. I held a consultation with Professor Wising and other medical friends. He placed himself en rapport with this patient, who heard and answered him, but neither me nor any other. She gave the idea that the stammering was so abolished that she could not be made to repeat it. This case induced me to study extensively the malady in question, which is not infrequent, and always deplorable. I have since treated for it at least twenty-six persons, and in most cases the results were encouraging. The pathology of it is well expressed in Colombat's work. ${ }^{1}$ Stammering, so far as I see, is never of organic origin, hence the inutility of Dieffenbach's operation. ${ }^{2}$ My cases were in 18 males from 27 to 5 years-6 cured, 10 improved, 1 no better, and 1 unknown; in 8 females from 32 to 5 years- 4 cured, 2 improved, and 2 unimproved."

In neuræsthenia, in which Weir Mitchell obtained so many brilliant results, Dr Wetterstrand had 17 cases, of which 6 failed, 4 cured, 4 blifvit förbättrade remained improved, and the rest under treatment. Cases of hysteria, amblyopia, nervous deafness, chronic alcoholism, and even rheumatism, appear to have been decidedly benefitted by the same agency.

In phthisis there is claimed for it a soothing euthanasia at the later stages, as also an improvement in cardiac pulsations, where he follows Dr Balfour, of Edinburgh, in discriminating between those

1 Traité de tons les vices de la parole et en particulier du bégaiement. Paris, 1843.

2 Rohlf's Geschichte der deutschen Medicin. Leipsic, 1885. Vol. iv. p. 150. 
of organic origin and nervous-trouble causation ; giving comparative sphygmographic tracings of the improvement effected by suggestions. Diarrhoa and vesical and renal maladies appear to come within the range of his experiments, as well as disorders of men-
struation.

On reading the 24th chapter, "Hypnotismens använding vid barnförlossning" (the Application of Hypnotism to Child Delivery), amused interest was felt. The case was a tall, well-developed matron of 25 in her sixth pregnancy; otherwise healthy, she complained of severe headaches, which impaired her memory and thinking power. She developed great susceptibility to hypnotism, and after some weekly séances was freed from cephalalgia. The case appeared most suitable for application of this agency to re-

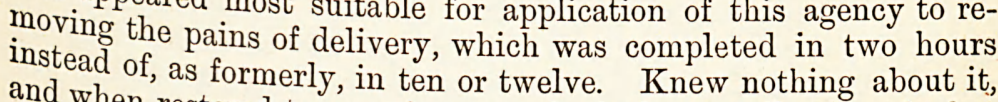
and when restored to consciousness she had no recollection of what was said or done; absence of after-pains, and had a complete recovery on the seventh day.

This and the numerous other cases related of the astounding successes obtained by Dr Wetterstrand are apt to give rise to a feeling that it is too good news to be altogether true, especially among us seniors, who have so frequently experienced in therapeutic applications that-

"The best laid schemes o' doctors, mice, and men Gang aft agley."

Yet there is every external evidence of scientific good faith in the ment, who is unmistakably far advanced in professional attainment, and well read in British, French, and German standard authorities. For those who have opportunities and aptitude for applying and experimenting in Braidism or hypnotism we would consider such as a perfectly legitimate modus operandi, and whatber benefit might accrue therefrom to suffering humanity would be so much pure gain.

At the Balneologisch Congress, held at Berlin 1st to 3rd March
1889, I paid a visit that Von Corval of Baden-Baden stated he had present at last year to Wetterstrand in Stockholm, and had been was not 800 séances. While contending that suggestie therapie which more dangerous than many other agencies in daily use, that hed also their disadvantages, as a pain-calmative he averred migraine, and witnessed surprising results in hysteria, cephalalgia, stammerers. the Congress The speaker strongly recommended the members of confidengress to apply suggestie therapie, and prove its claims to attainable. $\mathrm{We}$ no.

Nordislct Medicin to consider the volumes (quarterly) of the edingurgh EDINURGH MED. JOURN., VOL. XXXV.-NO. III. 
Axel Key, Professor of Pathological Anatomy - a substantial-looking publication, with papers in Swedish and Danish, and medical notices from Sweden, Denmark, Norway, and Finland. The first paper that merits notice is one by Dr Emil Rode, on the Signs still existing after Involution Period of a previous Pregnancy (Tegn, efter Involutiens-perioden, pö Forudgäet Födsel). This paper is based on the journals of the Maternity of Christiania, on the experience of the author in private practice, and on a certain number of autopsies.

Dr Rode attaches the chief importance to the uterus. Among nullipara the vaginal portion of it forms a small cone, while with those who have borne children this portion is flattened equally before and behind as up and down. Among the sterile Dr Rode found the os ext. uteri was oval in 83 of 168 cases investigated, and circular in 72 per cent. of 449 cases of primipara. The aperture was transverse in 60 per cent. of 20 females examined postmortem. In those who have been delivered of fully developed children, the os was transversely elongated, and one-half with indentations.

To the total length of the uterus Dr Rode does not attribute an absolute importance, but this is much greater when the length above mentioned is compared with the distance of the orifices. As to this point it was constantly observed that in women who had given birth to children at full time it is always 2.50 to $2.00 \mathrm{~cm}$., a dimension never noticed in nullipara. To the mammæ he attaches little significance, seeing that all the special signs they offer might be found in virgins; only the white spots found in the secondary circle surrounding the areola is only found in females who have been pregnant, and even among them these spots are rare. This laborious and elaborate paper is illustrated with five plates, in which every possible aspect of the os uteri is delineated.

The next is "Om Snöblindhet," af Med. L. Aug. Berlin,- "On Snow-blindness," by Dr Aug. Berlin.

This malady has been hitherto regarded as a lesion of the interior parts of the eye, an irritation of the retina and optic nerve, originating in the intense reflection of the light by snow. Liber regarded it as an exaggerated dazzling. Some admit a relation with hemeralopia and nyctalopia.

Physicians who have studied cases of this kind for themselves have been forced to lay much stress on the symptoms of conjunctival irritation, or, with Reich, they have explained it as a reflex dazzling, or, with Schiess Gemuseus, as a combination of the two.

The author, who himself had occasion to observe this eye trouble during the expedition of Nordenskiöld to Greenland in 1883, has devoted a special study to it, from which he has been led to form opinions directly opposite to those which previously prevailed. After having gone over nearly all the histories of the Arctic voyages, and weighing cases mentioned in ophthalmological literature, $\mathrm{Dr}$ 
Berlin has collected sufficient material to enable him to determine pretty exactly the geographical extension of the disease. This is very characteristic. Snow-blindness presents itself as far north as the Arctic regions have been hitherto explored, while on the south it never oversteps certain degrees of latitude. On the American and Asiatic continents it extends farther than in Europe. In America it descends to $53^{\circ} \mathrm{N}$. lat., whereas it is unknown in Scandinavia. A map which accompanies the original Svensk displays clearly the Arctic territory of snow-blindness, where the meridional limit follows all the sinuosities of the isothermals of this portion of the globe.

To the south of this district the malady occurs sporadically only on the highest mountains, such as the Alps, Caucasus, and also on some equatorial summits. In the Arctic regions it is severest in the spring, but is met sometimes in summer, especially where snow remains on glaciers. The disease is produced not only when the sun appears, but also when tempests and snowstorms
occur.

The symptoms are-intense burning pain in the eyes, commencing with a stinging sensation as if a foreign body was present; augmented tear secretion; photophobia and blepherospasm. At first hyperæmia of the bulbar conjunctiva, then of the eyelids; chemosis, and in grave cases dulness and dimness of the cornea. The pupils are contracted, and the fundus oculi slightly hyperæmic; the visual power not diminished, but only contracted by the foregoing symptoms. If the patient be withdrawn from the originatbut in morbid influence, the malady is cured in two or three days; destrut some other cases corneal ulcers occur, and even more diminutive processes, ending in loss of sight. Excepting these, no ness. Som of visual power remains as a consequence of snow-blindto the Sometimes only one eye is attacked-the one mostly turned The side of the sun. Animals also are subject to this affection. feeble symptoms, as well as the manner in which they arise, enwhen the supposition that dazzling is the cause of them. In fact, when dazzling results from a person imprudently gazing at the parts of is no pain felt nor any sign of irritation of the anterior dimin the eye; but, on the contrary, it produces a persisting in snow-h of the field of vision, and vertigo, which never appears explanationdness. The rarefaction of the air does not give much xplanation.

The regions where it prevails are remarkable for their low temperatures and consequent diminution of the absolute humidity of the air. As it is chiefly the atmospheric humidity that absorbs the radiating heat, the calorific rays of the sun must exercise in these localities an intensity of action much superior to their usual intensity. Now, this is the fact. On high mountains and in Arctic regions, insolation produces in the naked skin a dermatitis excessively painful, and the radiating heat reflected by snow 
redoubles the effect. From direct observation it appears that in these parts insolation attains its maximum in the spring.

It would be more than extraordinary if, under the dominion of such circumstances, the eyes should remain exempted from the pernicious influence of the calorific sun-rays. In fact, the eyes are often scorched simultaneously with the skin or a little before. It is exactly the same process-hyperæmia of the skin and conjunctiva, then serous exudation, followed by the intense smarting characteristic of snow-blindness. The congestion of the retina is easily explicable by the violent irritation of the conjunctiva. The author rejects the theory that the retinal hyperæmia is a first product of the insolation. He relies, among others, on the experiments of Janssen, showing that the retina is only acted upon by an insignificant proportion of calorific rays.

This erythema conjunctivæ, as Dr Berlin entitles the malady, is equally produced by mechanical irritants, such as the snowy particles that strike the eye during snow-storms, or by the fine, jaggy ice-needles borne in by them.

The author advances the supposition that a milder form of snow-blindness is seen beyond the regions indicated. The conjunctivitis phlyctenulares that manifest themselves at the beginning of spring he also attributes to insolation.

The aborigines of these snowy regions employ, as a preservative against this painful ophthalmia, snow-spectacles made out of a piece of wood provided with a transverse cleft, or by a network of wire or of hair, of which a figure is given, also a picture of the spectacles-a metallic frame with coloured glasses and network iron sides-which are used in Arctic voyages and travels to protect the eyes, but which, unluckily, are easily covered by damp or snow on the glasses, hence the author advises their being entirely made of iron network. After the ophthalmia is once established, coloured glasses are useful for the concomitant photophobia.

For the treatment of the malady vinum opii and sulphaszinci lotions have been hitherto employed, but Dr Berlin recommends for future expeditions the use of cocaine.

Immediately following the communication just noticed is a paper in Danish " Om Aleute Trofonevroses hos Sindssyge, sarlig den diffuse Flegmone," af Reserveläge Helweg,Aarhus, Sindessygeanstalt) "On the Acute Trophonevroses of the Insane, and especially the Diffused Phlegmons," by Rv. Helweg, Aarhus Asylum, Jutland. The author has had occasion to notice that diffused phlegmons occur more frequently in lunatic asylums than outside these establishments, and was inclined to infer that some causal relation existed between this malady and the pathological alterations of the nervous system of the insane, or, in other terms, that there were grounds for regarding it as a trophoneurosis. In the first place he founded this view on the frequency of diffused phlegmons among that class of patients. The list of somatic maladies among 
the insane in the Asylum of Aarhus (Jutland) for five years shows that this malady furnished a percentage of $2 \cdot 4$ of the cases, a figure which must be regarded as considerable. Besides, these phlegmons occur only in the most serious cases of mental diseases, where the most profound alterations of the central nervous system present themselves, and among these they come spontaneously without external causes.

Dr Helweg demonstrates the affinity between these pathological conditions, showing odema and diffused erythema are introductory to the phlegmon, - on the back leading to dermatic gangrene, and on the sides to anthrax, carbuncle, ecthyma, etc. In support of his view of this affinity he gives details of seven cases, in six of which, followed by a careful anatomic investigation of the spinal cord, different parts of the peripheral nerves, the muscles, etc., displaying grave alterations found in many of the organs without local symptoms to account for them- the patient presenting a sort of general degeneration, with degeneration of the functional tissues of the organs.

In these, besides the chronic myelitis characteristic of insanity of old standing, acuter focal processes in various sections of the spinal cord were found, which the author places in relation with the acute trophoneuroses. Comparative examination showed, as previously pointed out by Charcot, that it is the central portion of the gray substance that is connected with troph. of the skin. He considers that Clark's columns have most to do with it, and the more acute the degeneration there, the more grave and violent the manifestations.

In the two last cases the post-mortem changes exactly corroborated the diagnosis made during life. The last case was of special interest. The patient of 48 showed a complete clinical picture of a subacute anterior cervical polyo-myelitis. After manifesting only slight symptoms, a sudden exacerbation occurred at the end of fifteen days, there being radiating paralysis of the two superior two tremities with paresis of the second group of their muscles. In two or three days he developed simultaneously a pneumonia on the right, an acute intestinal catarrh, acute arthritis of the left knee, and a diffuse phlegmon of the left femur and leg. The paresis disappeared more or less in the course of some weeks along with the intestinal catarrh, the pneumonia became indurated, and the arthritis acquired the aspect of white swelling. As regards the diffused phlegmon, he suppurated a whole year. Then gangrene developed itself in the parietes of the femoral abscess cavities, passing on to the popliteal artery, causing fatal arterial hæmorrhage. The autopsy discovered a sclerosis of the central part of the gray substance in the inferior portion of the cervical spinal marrow and the superior portion of the dorsal, extending to the anterior gray cornua-the ganglion-cells of which were deeply 